\title{
A CASE OF CYLINDROMA AT THE RADIX OF THE TONGUE AND THE PHARYNX WITH ADENOMA OF THE THYROID
}

By

Kozo SAKAKURA, M.D., ToshiKi INOUE, M.D.

and Yosho TERADA, M.D.

\section{From the Clinic of Oto-Rhino-Laryngology, Kawasaki City Hospital}

\begin{abstract}
A 55old female, had the tumor at the radix of the tongue and the pharyngeal portion, with the large struma of the anterior cervical area for long time. Symptome of this tumor was coverd by the tumor of the thyroid, and it was regared the invasion from the thyroid tumor. But the
\end{abstract}

postmortem examination revealed that this tumor was the cylindroma and it was independent of the thyroid.

And the consideration on the characteristics of cylindroma were briefly. made.

\section{甲状腺々腫を伴う舌根及び咽頭部円柱腫の一例}

\author{
川崎市泣病院耳㸶喉科

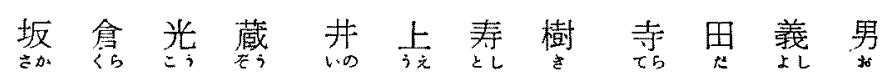

\section{緒言}

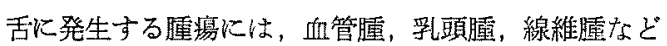
の良性垕瘍と共に, 扁平上皮癌が数多くみられる、しか し，それらの殆之恬垁上り舌縁にかけてみられるるの が多く，舌根部に発生する腫場には舌根甲状腺以外には 余り報告以接しない。

私達はこの度，巨大なる頸部甲状腺々䀯を伴う，舌根 の円柱腫の一例飞遭遇し，その余りに著しい甲状腺所見 に陰蔽されて，診断をつけるのに苦心した症例を経験し たので,こ〉に報告する。

\section{症例}

55 才，女，

初診：昭和 39 年 5 月 26 日

主訴：呼吸困難

初診迄の経過：当患者は若い頃より前頸部の蕾脤を 訴えて括り，当時より某病院にて甲状腺々腫と診断され ていたが，甲状腺による中袁症状汭なく，钼血的には治 療をうけていなからた。しかし，前頸部の腫瘤は、こつ 2〜3年来，や小急速に增大を示してきていた．本年3月 始め，気分不良にて倒れ，ある病院にて内服薬を投与さ れていたが，5月始めより呼吸困難，発声障碍を訴える
ようになつてきた。しかし，特別な治療はうけなかつ た。 5 月 25 日乎吸困難が 急激に烈しくなつたために， ある甲状腺専問の病院に入院し，その翌日当院へ転送さ れてきた。

既往歴，家族歴共に特記すべきものはない，

初診時所見：患者は体格中等度で，や入瘦せ鴽味で

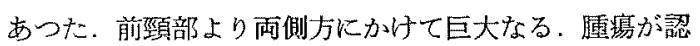
められた，硬度はや〉硬く中に 2 3 個所程特に硬い部 分をふれたが, 圧痛, fluctation は認められなかつた。 又顔乱，潰瘍，罗死などの部分も見られなかつた。発声 は殆ど不可能であり，呼吸困難は非常に高度であつた。 しかし，その他の 全身状態には異常を認められなから た。このため即日入院せしめた。

入院後の経過：呼吸困難が 極めて 強かつたために， 直ちに気管切開を行つた。、気管切開を行つたが，甲状 腺が巨大なるために，手術にかなりの困難を伴つた。 そ の際甲状腺の一部をプローベとしてとり，本院検查科比 て病理組織学的檢索を行つたが, 甲状腺々腫にて悪性像 は認められないという返事を光た（第1図），その他の 諸検查事項は赤血球 376 万, 血色素 $12.3 \mathrm{~g} / \mathrm{dl}$, 白血球 5,900にて，や〉筫血気味であつたが，血液像注異常 
第 1 表 血 液 所 見

第 1 図甲状腺組織（腺随）

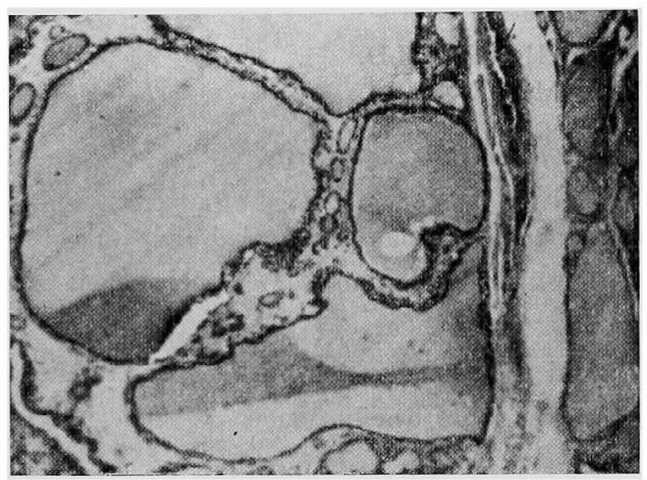

\section{$5 / 10 / 1 / 4 / 7 / X$}

\begin{tabular}{|c|c|c|c|c|c|c|c|}
\hline & & & $10 / \mathrm{VI}$ & $4 / \mathrm{VII}$ & $5 / X$ & $2 / X I$ & $11 / \mathrm{I}$ \\
\hline 赤 & 血 & 球 & $376 \times 10^{4}$ & 320 & 218 & 279 & 236 \\
\hline 血 & 色 素 & 量 & $12.3 \mathrm{~g} / \mathrm{dl}$ & 10.4 & 6.8 & 9.9 & 7.8 \\
\hline \multirow[t]{2}{*}{ 白 } & 血 & 球 & 5900 & 5500 & 2300 & 4000 & 5500 \\
\hline & $\begin{array}{l}\text { 好 酸 } \\
\text { 好 塩 基 }\end{array}$ & & $\begin{array}{l}4 \% \\
0 \%\end{array}$ & $\begin{array}{l}1 \\
0\end{array}$ & & $\begin{array}{l}0 \\
0\end{array}$ & $\begin{array}{l}1 \\
0\end{array}$ \\
\hline \multirow[t]{2}{*}{ 百 } & 桿 状 & 球 & $4 \%$ & 1 & & 12 & 19 \\
\hline & II & 核 & $30 \%$ & 40 & & 49 & 35 \\
\hline \multirow[t]{2}{*}{ 分 } & II & 核 & $18 \%$ & 29 & & 10 & 8 \\
\hline & IV & 核 & $2 \%$ & 1 & & 0 & 0 \\
\hline \multirow[t]{3}{*}{ 比 } & V & 核 & $0 \%$ & 0 & & 0 & 0 \\
\hline & リンパ & & $36 \%$ & 24 & & 24 & 32 \\
\hline & 単 & 球 & $6 \%$ & 4 & & 5 & 5 \\
\hline
\end{tabular}

第 2 表血液理化学 検査

\begin{tabular}{|c|c|c|c|c|c|c|c|c|}
\hline & $10 / \mathrm{VI}$ & $13 / \mathrm{VII}$ & $4 / \mathrm{VWI}$ & $21 / \mathrm{VW}$ & $5 / X$ & $2 / X I$ & $24 / X]$ & $12 / \mathrm{I}$ \\
\hline 白 & $7.2 \mathrm{~g} / \mathrm{dl}$ & 6.8 & 7.0 & 7.8 & 5.0 & 6.2 & 7.0 & 6.4 \\
\hline $\mathrm{A} / \mathrm{G}$ 比 & 1.2 & 1.24 & 0.66 & 1.05 & 0.88 & 0.61 & 0.49 & 0.33 \\
\hline $\mathrm{Na}$ & $147 \mathrm{mEq} / l$ & 140 & 141 & 141 & 145 & 123 & 145 & 139 \\
\hline $\mathrm{K}$ & $5.05 \mathrm{mEq} / l$ & 4.05 & 4.45 & 3.9 & 3.4 & 2.2 & 2.9 & 3.1 \\
\hline $\mathrm{Ca}$ & $4.97 \mathrm{mEq} / l$ & 3.3 & 2.6 & 3.5 & 2.7 & 2.77 & 2.6 & 2.07 \\
\hline $\mathrm{Cl}$ & $100 \mathrm{mEq} / l$ & 100 & 91 & 99 & & 88. & 97 & 95 \\
\hline$P$ & $3.7 \mathrm{mg} / \mathrm{dl}$ & 3.1 & & 5.9 & & 4.7 & 5.0 & 5.2 \\
\hline $\begin{array}{l}\text { アルカリフォス } \\
\text { フォター }\end{array}$ & & 3.0単位 & 4.0 & 5.3 & & 9.4 & 6.7 & 15.6 \\
\hline $\mathrm{P} \quad \mathrm{N}$ & $20 \sim 30 \mathrm{mg} / \mathrm{dl}$ & & & & & & & \\
\hline
\end{tabular}

を認めなかつた (第 1 表)，血清検査にては総蛋白 7.29 $\mathrm{g} / \mathrm{d} l, \mathrm{~A} / \mathrm{G}$ 比 $1.2, \mathrm{Na} 147 \mathrm{mEq} / l, \mathrm{~K} 5.05 \mathrm{mEq} / l, \mathrm{Ca}$ $4.97 \mathrm{mEq} / l, \mathrm{Cl} 100 \mathrm{mEq} / l$, 無機燐 $3.7 \mathrm{mg} / \mathrm{dl}$, 残余窒素 $20 \sim 30 \mathrm{mg} / \mathrm{d} l$ にて $\mathrm{Ca}$ 值も正常であつた (第 2 表). 尿所見は蛋白 (一), 桾 (一), ウロビリン (一), ウ口 ビリノーゲン (十), ビリルビン (一), 肝機能 検查は B.S.P. 45 分後 $0 \%, \mathrm{CCF}(H)$ 飞て異常所見は認め方 れなかつた。

入院後も，巨大な腫劰により，カニューレが入りにく く，呼吸困難をおこしがちであつた．しかし，前頸部の : 腫瘍は特別に增大を示さなからた。

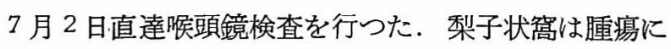
て蔽われ，㗋頭内部迄検查する事は不可能であつた。

以上の所見より私達は, 甲状腺腫瘍はプローベの恰査
にては良性の腺腫であるが，一部に悪性変化をおこした 部分があり．それが咽頭内部に浸潤してきたものと考兄 たために，甲状腺腫瘍摘出術特よび，腨頭全摘出術を 行う事にした。7月9日全身麻酔下に，この手術を行つ た. 甲状腺腫瘍は両葉にわたり、気管切開孔附近にて, 気管と強く㾑着していたために，同部にて気管を切断 し，その下部断端を皮或之縫合し，呼吸孔とした，上方 は䐅頭との瘉着は強くなく, 容易汇遊離出来, 又上皮小 体の存在も気になつたために，呢頭摘出は行はず，気管 断端を縫合し，結局，甲状腺腫瑒と，気管の一部を摘出 したのみにて，手術を終つた，上皮小体については前述 した如く，充分注意したにも拘らず，術後翌日より上下 肢にしびれ感を訴えるようになり，上肢にテタニー特有 の姿態をとるようになつた，血清 $\mathrm{Ca}$ 值も第 2 表に示寸 
如く，術後減少し始め, 正常值の約半分位の值を示すよ らになつた. 叉そのために心蔵伝導系にも異常を生じ,

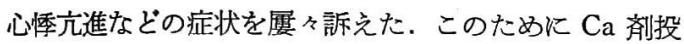
与を死迄続け，途中よりはかなり大量を投与しなけれ ばならなかつた.

切除した甲状腺㣖平滑な表面を有し，割合限局してお $\eta$ ，中に 2 個所程硬い所を認めた（第 2 図）。それの病 理組織学的所見も前回のものと同様で，良性の腺婳であ った.

\section{第 2 図甲状腺腫笏}

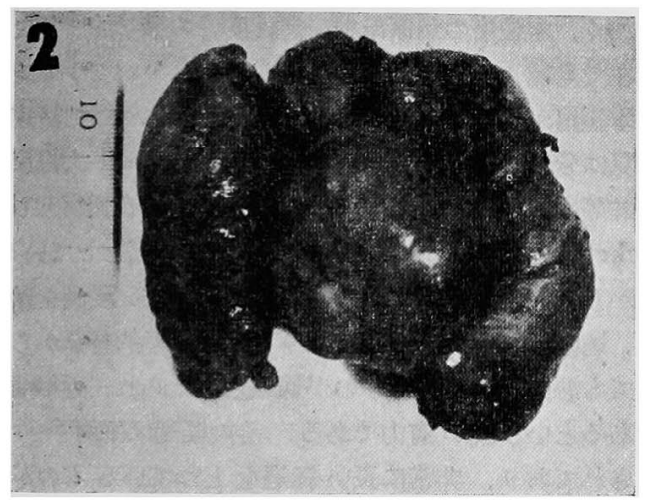

手術後約 10 日程してから，舌根部の腫瘤に気がつい た．位置は舌根扁桃の部分にあたり，表面凹凸のある出 血しやすいものであつた．この部よりプローべをとり病 理組織学的検索を行つた所, 孚嘴蕾様腺癌の疑にて, 甲状 腺由来が充分考兄られるとの返事をえた，その後はレン トグン深部照射 2800r., 制癌風たるエンドキサン, トヨ マイシンを各 26 筒づつ投与し，その他は対症的に処置 した. 9 月に入つてからは舌根部の腫瘍が壊死に阫り，数 回に亘り大出血をきたし，一時は全身状態むかなり悪化 した. しかし本患者は，この頃既に静脈注射が不能にな ク，輸血もできず, 貧血, 血清蛋白值も悪化が著明であ

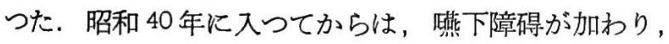
流動食を胃ゾンデより注入する方法より他なく，栄養障 碍が更に高度となり, 舌根部腫痬は增大乙 (第 3 図), 前 頸部気管切開孔附近より腫湟が露出しきたり (第 4 図), 同部が漬湯状を呈するようになり，全身状態は悪化の一 途を辿り，昭和 40 年 3 月 27 日鬼籍に入つた。

剖検所見：腫湯は舌根部より 咽頭部, 喉頭部に充満 し, 気管上部に迄浸潤し, 更に前頸部皮暍を侵し, 休表 面に迄露出してきていた（第 5 四），又頸部扣よび絎隔
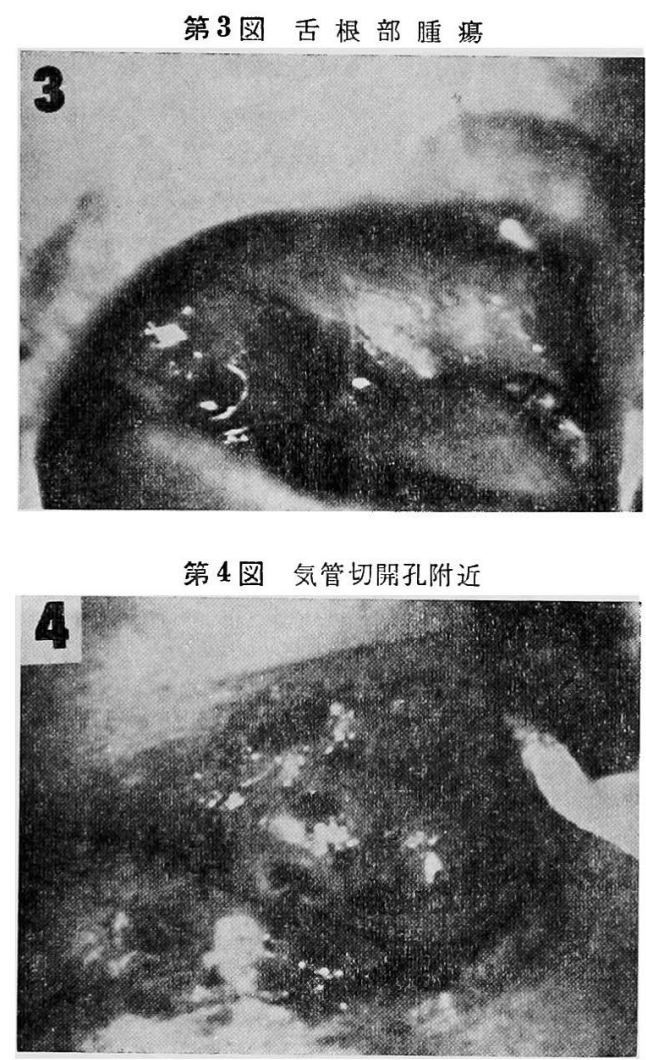

第 5 図 剖検により摘出せる原発挝源

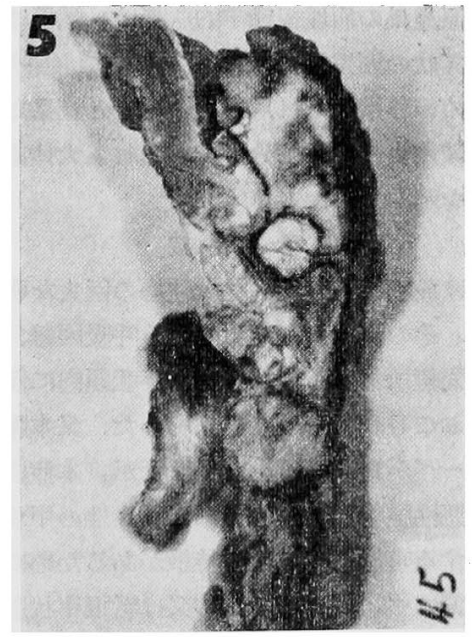

リンパ腺に転移し, 肺臓, 肝臓に点状の小転移巣を少数 認めたが，大きな転移巣は認められなかつた，又その他 の臓器には肉眼的には枟移巣は見られなかつた。 


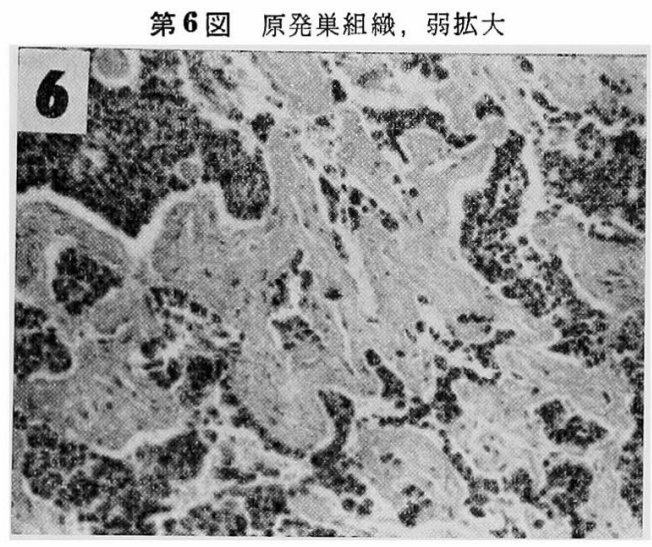

第 7 図 旰嫧転移巣組織, 強拓大

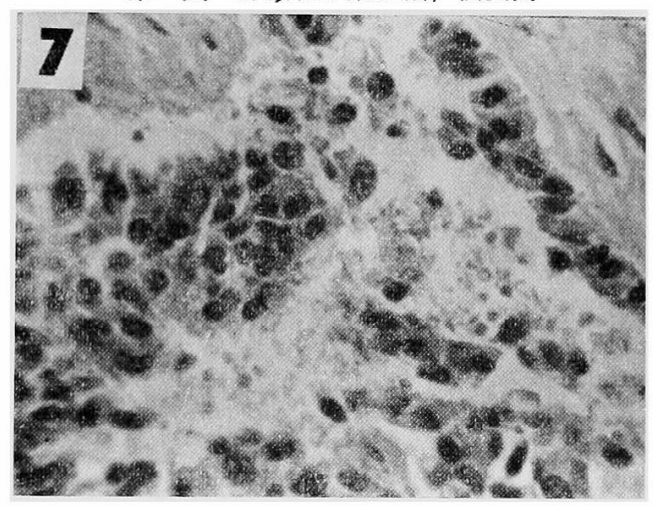

咽頭部原発巣の病理組織学的所見は，脜瘍は豊富な間 質の間に索状の癌組織の增生が 見られた（第6 図)，脯 臓，肝臓の転移巣のそれる索状の增生と豊富な間質，間 質中に粘液産生を示す部分も認められ，大体原発巣子同 様な所見を示していた（第7 図).

$$
\text { 考按 }
$$

本腫瘍は最初は私達は甲状腺腫瘍の巨大な所見に気を とられて，その呈した主症状である呼吸因難，発声障碍 を，又啹頭鏡所見も，甲状腺腫湯が咽頭内に侵入し，そ のために抗こされたものと考光ていた，又本腫瘍より光 たるプローべが良性の所見を呈したが，本症はやはり臨 床的には悪性腫瘍であり, 更に又, 良性の甲状腺腫瘍に ても転移する可能性を有する特徵があるために, 舌根部 の悪性腫瘍は甲状腺よりの転移又は舌根甲状腺の悪性変 化によるものと考光ていた．乙かし剖検所見より考察し

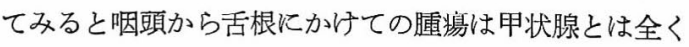
別個のものであり, この腫瘍は以前より存在し, 除々に 增大してきていたものであろう，これの增大するにつれ
て，咽喉部を满たし，気道閉塞し，主病状を呈するよう になつたるのと推察される。

又組織学的所見より考克ると，舌根より咽頭にかけて の腫瘍は豊富な間質を有し，その間に索状の癌組織が見 られる事などょりみて，円柱蕾と考えるのが妥当と思わ れる.

円柱腫は 1842 年 Ancell が始めて報告し，1856年 Billroth が Zylindrom なる 名称にて報告した稀な缠 瘍である。それ以後も種々の名称にて報告されてい る. 即ち, Epithelioma, Endothelioma, Adenoid cystic carcinoma など呼ばれている。 それらの名の示 す如く, 本堙瘍の病原母地, 悪性度, 組織学的所見など 現在でも種々の論議がなされている.

本腫瘍が良性であるか，悪性であるかについて諸家の 意見は分れているが, Borgschulte, Hamperl 大根田, 坪井等は良性と考克て敊り，Willis は混合腫湟とし， Ackermann, Dockerty, 深井等は悪性の癌としている. しかし本症の臨床経過から考兵ると, 再発, 浸潤を繰返 乙, 遠隔転移を伴う董瘍であり, 又組織学的特徽から考 光ても悪性腫瘍と見なすのが適当と考兄られ，近年は癌 であるという説が有力である，その経過恃平均 5 6 年 とされて呿り，非常に長い経過をとつているすのが多

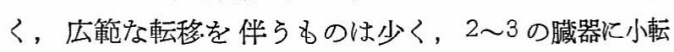
移巣を認めるものが多い上らである，むしろ原発巣の浸 潤傾向の強いのが特徴である.

発生母地としては, 重液腺, 粘液腺, 漿液腺の排泄管 上皮に求められて括り, そのために, 皮虞, 垂液腺の 他, 咽喉頭, 口腔, 鼻腔, 副鼻腔にも出現するが, 本来 この腫揚は非常に稀なものである.

組織学的特徵としては節状構造, クロマチンに富む細 胞の島㟪状集団, 間質に和ける硝子様物質の存在, 又汗 管様構造などが挙げられている.

私達の経験した症例も，永い経過をとり原発巣より 周辺組織之の非常に強い浸潤力をるち, 且つ遠隔臟器え の転移は数少い小転移巣のみであつた，組織学的にも， 豊富な間質の間に見られる索状構造をなす細胞集団, 粘 液産生を示す部分など，や子非定型的ではあるが，円柱 腫と診断して差支えないと思われる。

本腫䁑は古くは内皮塊説が強からたが，最近では上 皮細胞由来の説が有力であり。そしてその名称も malignant Cylindroma 乃至 Foote \& Frazel の唱えた Adenoid cystic carcinoma と呼ぶのが適当とされてい る. 


\section{結語}

私達は55才女子にて以前より前頸部に巨大なる甲状 腺々尰を伴ら咽頭舌根部腫瘍の一症例を経験した。本腫

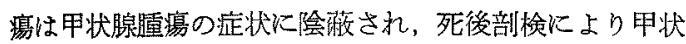
腺とは別個な円柱透である事が判明した。

又, 円柱腫につき，その特袮を簡単に考察した。

\section{文 献}

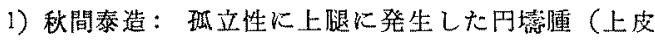

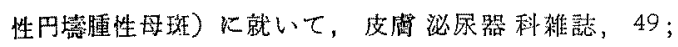

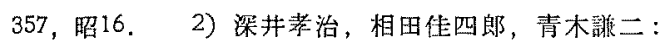
広沉な移をたした所謂円柱腫 (Cylindroma) の2 剖検例, 北関東医学, 13;93, 昭83,3) 本店正一, 三宅清美，伊藤喜久子，桑原敦子：钼腔に発生した円 柱性内被䋖胞腫症例，耳鼠咽喉科，21；343，昭24.

4) 㠇見覚一：學腔に発生せる「チリンドローム」に就
て, 大日两会報，23；233，大6.5)坪非尚，中野進：

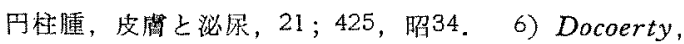
M.B. \& Mayo, C.W.: Primary tumor of the subm. axillary gland with special reference to mixed tumors, Surg. Gynecol. \& Obst., 74; 1033, 1942. 7) Foot, W.F. \& Frazell, E.L.: Tumor of the major salivary gland, Cancer, 6; 1065, 1953. 8) Willis, R.A.. Pathology of tumors, 3rd Edition, Butter Worth, London, 1950.

本稀交の要貣は日本耳率咽喉科学会第48回大 会（昭和40年9月26日）にて口演した。

（原剩到着=昭和40.10.25日） 